\title{
Role of diagnostic hysterolaparoscopy in the evaluation of infertility
}

\author{
Ami V. Mehta, Akshesh P. Modi*, Bina M. Raval, Sanjay P. Munshi, \\ Shefal B. Patel, Shakera M. Dedharotiya
}

\author{
Department of Obstetrics \& Gynaecology, V. S. Hospital, Ahmedabad, Gujarat, India
}

Received: 14 December 2015

Accepted: 08 January 2016

*Correspondence:

Dr. Akshesh P. Modi,

E-mail: draksheshmodi@gmail.com

Copyright: (C) the author(s), publisher and licensee Medip Academy. This is an open-access article distributed under the terms of the Creative Commons Attribution Non-Commercial License, which permits unrestricted non-commercial use, distribution, and reproduction in any medium, provided the original work is properly cited.

\begin{abstract}
Background: Infertility has become nowadays not only a medical, but a social problem as well. None of the laboratory findings alone is conclusive in diagnosing infertility. Diagnostic hysterolaparoscopy is an accurate method of assessing and treating infertility. Direct visualization of abdominal and pelvic organs in hysteroscopy and laparoscopy allows a definite diagnosis where clinical examination and less invasive techniques such as ultrasound, SSG and HSG fail to identify the problem. The main objective of study was to determine the role of diagnostic hysterolaparoscopy in the evaluation of infertility in tertiary care centers.

Methods: A prospective hospital based study was carried out in two tertiary care centers (Sheth V.S. General Hospital and Smt. S.C.L. Municipal Hospital) over a period of 2 years from July 2013 to June 2015. Hysterolaparoscopy was done in 300 patients. Women aged 20-40 years with normal hormone profile without male factor infertility were included.

Results: Out of 300 cases, $206(69 \%)$ patients had primary infertility. While laparoscopy detected abnormalities in $35 \%$ of the cases, significant hysteroscopy findings were noted in $17 \%$ of cases. Together, diagnostic hysterolaparoscopy detected abnormalities in $26 \%$ of the infertile patients in both groups. While the most common laparoscopic abnormality was endometriosis (14\%) and adnexal adhesions (12\%) in primary and secondary infertile patients respectively, on hysteroscopy, intrauterine septum was found as the commonest abnormality in both the groups.

Conclusions: Hysterolaparoscopy is an effective diagnostic tool for evaluation of certain significant and correctable tubo-peritoneal and intrauterine pathologies like peritoneal endometriosis, adnexal adhesions and subseptate uterus, which are usually missed by other imaging modalities.
\end{abstract}

Keywords: Hysteroscopy, Laparoscopy, Infertility

\section{INTRODUCTION}

Infertility affects about $10-15 \%$ of reproductive age couples. ${ }^{1}$ WHO estimates that 60 to 80 million couples worldwide currently suffer from infertility. ${ }^{2}$ Incidence of female infertility is $45.67 \%$, male infertility is $54.33 \%$ and may be both can get involved in some of cases, range varies from region to region. ${ }^{3}$ Total infertility is divided into primary and secondary infertility.
Definitions of primary infertility vary between studies, but the operational definition, put forth by the WHO, defines primary infertility as "Inability to conceive within 12 months of exposure to pregnancy (i.e. sexually active, non-contracepting and non-lactating) among women 15 to 49 years old". 4 Secondary infertility refers to the inability to conceive following a previous pregnancy. Unexplained infertility is infertility that is idiopathic in the sense that its cause remains unknown even after an 
infertility work-up, usually including semen analysis in the men and assessment of ovulation and fallopian tubes in the woman. Globally, most infertile couples suffer from primary infertility. ${ }^{5}$

Though ultrasound and other laboratory investigations are necessary, the ability to see and manipulate the uterus, fallopian tubes, and ovaries during laparoscopy has made it an essential part of infertility evaluation. ${ }^{6,7}$ Similarly, visualising the uterine cavity and identifying the possible pathology has made hysteroscopy an equally important tool in infertility evaluation. The question of tubal morphology and patency, ovarian morphology, any unsuspected pelvic pathology, and uterine cavity abnormalities can all be resolved with accuracy at one session.

This study was undertaken to evaluate the role of diagnostic hystero-laparoscopy (DHL) in the comprehensive work up of infertility, which would help in planning appropriate management.

The benefits of the laparoscopic approach to surgery include more precise surgery, superior haemostasis, less tissue handling, less pain, improved cosmetics, short convalescence, reduced cost and quicker recovery.

\section{METHODS}

This prospective study of 300 cases was conducted in two tertiary care centres (Sheth V.S. General Hospital and Smt. S.C.L. Municipal Hospital) over period of 2 years from July 2013 to June 2015.

Male partner's seminal fluid examination was done and was normal.

Ultrasound and basic investigations were done and normal.

Each patient was admitted a day prior to the procedure. All the patients were kept nil by mouth after $10 \mathrm{pm}$ a day before surgery.

After taking written and informed consent, Laparoscopy was performed during the post-menstrual phase on $7^{\text {th }}, 8^{\text {th }}$ and $9^{\text {th }}$ day of cycle under general anesthesia with endotracheal intubation.

The hysteroscope was introduced into the cervical canal under vision. The uterine cavity was distended with $0.9 \%$ normal saline and examined.

Pelvic organs were examined and then whole peritoneal cavity was examined.

After the procedure, patient was transferred to postoperative ward and was discharged next day.

\section{RESULTS}

Out of 300 patients, $206(69 \%)$ women had primary infertility and the rest $(31 \%)$ had secondary infertility. The patients in secondary infertility group were slightly elder compared to primary group $(28.8 \pm 3.7$ versus $31.1 \pm 4.5$ years). But there was no difference in duration of infertility in both the groups $(4.8 \pm 3.2$ versus $4.5 \pm 2.9$ years).

In primary infertility group, laparoscopic abnormalities were more common (Table 1) than hysteroscopy (35\% versus 17\%). Endometriosis and adnexal adhesions were the most common abnormalities detected in laparoscopy in primary and secondary infertility groups respectively (Table 2). The most common intrauterine pathology in both the groups was uterine septum (Table 3). Out of 29 patients diagnosed with septate uterus, only 1 patient had complete uterine septum that falls under the primary infertility group. Multiple abnormalities were also detected; laproscopically in 30 patients and hysteroscopically in 4 patients (Table 4). The prevalence of unilateral and bilateral tubal block was equal in both the groups (Table 5). 9\% patients developed minor complications, of which gaseous distension of the abdomen was the most common. There was no major surgical or anaesthetic complication in any of the patients (Table 6).

Table 1: Prevalence of hysteroscopy and laparoscopy abnormalities.

\begin{tabular}{|c|c|c|c|c|c|}
\hline \multirow[t]{2}{*}{$\begin{array}{l}\text { Proced } \\
\text { ures }\end{array}$} & \multicolumn{2}{|c|}{$\begin{array}{l}\text { Primary } \\
(206)\end{array}$} & \multicolumn{2}{|c|}{$\begin{array}{l}\text { Secondary } \\
(94)\end{array}$} & \multirow{2}{*}{$\begin{array}{l}\text { Abnor } \\
\text { mal } \\
\text { findin } \\
\text { gs }\end{array}$} \\
\hline & $\begin{array}{l}\text { Norm } \\
\text { al } \\
(\%)\end{array}$ & $\begin{array}{l}\text { Abnor } \\
\text { mal } \\
(\%)\end{array}$ & $\begin{array}{l}\text { Norm } \\
\text { al } \\
(\%)\end{array}$ & $\begin{array}{l}\text { Abnor } \\
\text { mal } \\
(\%)\end{array}$ & \\
\hline $\begin{array}{l}\text { Laparo- } \\
\text { scopy }\end{array}$ & $\begin{array}{l}133 \\
(65)\end{array}$ & $\begin{array}{l}73 \\
(35)\end{array}$ & $\begin{array}{l}66 \\
(70)\end{array}$ & $\begin{array}{l}28 \\
(30)\end{array}$ & 101 \\
\hline $\begin{array}{l}\text { Hystero } \\
\text {-scopy }\end{array}$ & $\begin{array}{l}171 \\
(83)\end{array}$ & $\begin{array}{l}35 \\
(17)\end{array}$ & $\begin{array}{l}73 \\
(78)\end{array}$ & $\begin{array}{l}21 \\
(22)\end{array}$ & 56 \\
\hline Total & $\begin{array}{l}304 \\
(74)\end{array}$ & $\begin{array}{l}108 \\
(26)\end{array}$ & $\begin{array}{l}139 \\
(74)\end{array}$ & $\begin{array}{l}49 \\
(26)\end{array}$ & 157 \\
\hline
\end{tabular}

Table 2 : Laparoscopy findings.

\begin{tabular}{|llll|}
\hline Findings & $\begin{array}{l}\text { Primary } \\
(\%)\end{array}$ & $\begin{array}{l}\text { Secondary } \\
(\%)\end{array}$ & $\begin{array}{l}\text { Total } \\
(\%)\end{array}$ \\
\hline Myoma & $10(05)$ & $05(05)$ & $15(05)$ \\
\hline Endometriosis & $31(15)$ & $10(09)$ & $41(12)$ \\
\hline $\begin{array}{l}\text { Adnexal } \\
\text { adhesions }\end{array}$ & $17(08)$ & $12(12)$ & $29(08)$ \\
\hline Tubal pathology & $13(06)$ & $08(08)$ & $21(07)$ \\
\hline $\begin{array}{l}\text { Ovarian } \\
\text { pathology }\end{array}$ & $17(08)$ & $05(05)$ & $22(07)$ \\
\hline $\begin{array}{l}\text { Uterine } \\
\text { anomaly }\end{array}$ & $03(01)$ & 00 & $03(01)$ \\
\hline Total & 91 & 40 & 131 \\
\hline
\end{tabular}


Table 3: Hysteroscopy findings.

\begin{tabular}{|llll|}
\hline Findings & $\begin{array}{l}\text { Primary } \\
(\%)\end{array}$ & $\begin{array}{l}\text { Secondary } \\
(\%)\end{array}$ & $\begin{array}{l}\text { Total } \\
(\%)\end{array}$ \\
\hline Myoma & $06(03)$ & $02(02)$ & $08(03)$ \\
\hline Polyp & $11(05)$ & $05(05)$ & $16(05)$ \\
\hline Septum & $18(09)$ & $11(12)$ & $29(10)$ \\
\hline Synechiae & 00 & $01(01)$ & $01(<01)$ \\
\hline $\begin{array}{l}\text { Foreign } \\
\text { body }\end{array}$ & $02(01)$ & $04(04)$ & $06(02)$ \\
\hline Total & 37 & 23 & 60 \\
\hline
\end{tabular}

Table 4 : Hysteroscopy and laparoscopy.

\begin{tabular}{|ll|}
\hline Findings & $\begin{array}{l}\text { No. of } \\
\text { patients }\end{array}$ \\
\hline Only Laparoscopy showing pathology & 101 \\
\hline Only Hysteroscopy showing pathology & 56 \\
\hline Both showing pathology & 34 \\
\hline Total & 191 \\
\hline
\end{tabular}

Table 5: Prevalence of tubal block (chromopertubation test).

\begin{tabular}{|llll|}
\hline Findings & $\begin{array}{l}\text { Primary } \\
(\%)\end{array}$ & $\begin{array}{l}\text { Secondary } \\
(\%)\end{array}$ & $\begin{array}{l}\text { Total } \\
(\%)\end{array}$ \\
\hline Unilateral & $21(10)$ & $09(10)$ & $30(10)$ \\
\hline Bilateral & $19(09)$ & $12(12)$ & $31(10)$ \\
\hline
\end{tabular}

Table 6: Complications.

\begin{tabular}{|ll|l|}
\hline Complications & No. of patients & Percentage \\
\hline Uterine perforation & 6 & $2 \%$ \\
\hline Bleeding & 3 & $1 \%$ \\
\hline $\begin{array}{l}\text { Gaseous distension of } \\
\text { abdomen }\end{array}$ & 18 & $6 \%$ \\
\hline Total & 27 & $9 \%$ \\
\hline
\end{tabular}

\section{DISCUSSION}

Tubal and peritoneal pathology accounts for the primary diagnosis in approximately 30 to $35 \%$ of infertile couples. ${ }^{8}$ The gold standard technique for diagnosing these disorders is laparoscopy, which is a better predictor of future spontaneous pregnancy in infertile couples with unexplained infertility. ${ }^{9}$ Jayakrishnan et al from India detected pelvic pathology in $26.8 \%$ cases of infertile patients by laparoscopic evaluation. ${ }^{10} \mathrm{We}$ got similar result (pelvic pathology: 30\%) in our study. In addition, endometriosis and adnexal adhesions were the two major abnormalities found among infertile patients in different studies similar to our findings. ${ }^{11,12}$

Uterine pathologies are the cause of infertility in as many as $15 \%$ of couples seeking treatment and are diagnosed in as many as $50 \%$ of infertile patients. ${ }^{13,14}$ Developmental uterine anomalies have long been associated with pregnancy loss and obstetric complications, but the ability to conceive is generally not affected. The pooled data suggest that the prevalence of septate uterus is similar in infertile and fertile women (approximately $1 \%)$, but is significantly higher in women with recurrent pregnancy loss (approximately 3.5\%). ${ }^{15}$ Septate uterus was the most common intrauterine abnormality in our study, which was undiagnosed by prior ultrasonography.

Other than septate uterus, the major hysteroscopic abnormalities in our study were myomas and polyps similar to another study. ${ }^{16}$ The evidence to suggest that uterine myomas decrease fertility is inferential and relatively weak; the bulk of it is derived from studies that had compared the prevalence of myomas in fertile and infertile women or the reproductive performance of women with otherwise unexplained infertility before and after myomectomy. ${ }^{17,18}$ Proposed mechanisms by which myomas might adversely affect fertility include cornual myomas that involve or compress the interstitial segment of the tube, dysfunctional uterine contractility interfering with sperm transport or embryo implantation, and poor regional blood flow resulting in focal endometrial attenuation or ulceration. The incidence of asymptomatic endometrial polyps in women with infertility has been reported to range from $10 \%$ to $32 \% .^{19,20}$ A prospective study of 224 infertile women who underwent hysteroscopy observed a $50 \%$ pregnancy rate after polypectomy. $^{21}$

\section{CONCLUSIONS}

Diagnostic hysterolaparoscopy is an effective and safe tool in comprehensive evaluation of infertility, particularly for detecting peritoneal endometriosis, adnexal adhesions, and septate uterus. These are correctable abnormalities that are unfortunately missed by routine pelvic examination and usual imaging procedures. Needless to emphasize that, it is a very useful tool that can detect various structural abnormalities in multiple sites like pelvis, tubes, and the uterus in the same sitting in patients with normal ovulation and seminogram. When done by experienced hands and with proper selection of patients, hystero-laparoscopy can be considered as a definitive investigative procedure for evaluation of female infertility. This helps in formulating specific plan of management.

Funding: No funding sources

Conflict of interest: None declared

Ethical approval: The study was approved by the Institutional Ethics Committee

\section{REFERENCES}

1. Boivin J, Bunting L, Collins JA, Nygren KG. International estimates of infertility prevalence and treatment-seeking: Potential need and demand for infertility medical care. Hum Reprod. 2007;22:150612. 
2. World Health Organization. Infecundity, infertility, and childlessness in developing countries. DHS Comparative Reports No 9. Calverton, Maryland, USA: ORC Macro and the World Health Organization; 2004.

3. Shamila S, Sasikala SL. Primary Report on the Risk Factors Affecting Female Infertility in South Indian Districts of Tamil Nadu and Kerala. Indian J Community Med. 2011;36(1):59-61.

4. Reproductive health indicators for global monitoring: Report of the second interagency meeting, 2001. Geneva: World Health Organization; 2001: 23.

5. Inhorn MC. Global infertility and the globalization of new reproductive technologies: illustrations from Egypt. Soc Sci Med. 2003;56:1837-51.

6. Makar RS, Toth TL. The evaluation of infertility. Am J Clin Pathol. 2002;117(Suppl):S95-103.

7. Fatum M, Laufer N, Simon A. Investigation of the infertile couple: should diagnostic laparoscopy be performed after normal hysterosalpingography in treating infertility suspected to be of unknown origin? Hum Reprod. 2002;17(1):1-3.

8. Miller JH, Weinberg RK, Canino NL, Klein NA, Soules MR. The pattern of infertility diagnoses in women of advanced reproductive age. Am J Obstet Gynecol. 1999;181:952-7.

9. Mol BW, Collins JA, Burrows EA, van der Veen F, Bossuyt PM. Comparison of hysterosalpingography and laparoscopy in predicting fertility outcome. Hum Reprod. 1999;14:1237-42.

10. Jayakrishnan K, Koshy AK, Raju R. Role of laparohysteroscopy in women with normal pelvic imaging and failed ovulation stimulation with intrauterine insemination. J Hum Reprod Sci. 2010;3:20-4.

11. Godinjak Z, Idrizbegovic E. Should diagnostic hysteroscopy is a routine procedure during diagnostic laparoscopy in infertile women. Bosn J Basic Med Sci. 2008;8:44-7.

12. Tsuji I, Ami K, Miyazaki A, Hujinami N, Hoshiai H. Benefit of diagnostic laparoscopy for patients with unexplained infertility and normal hysterosalpingography findings. Tohoku J Exp Med. 2009;219:39-42.

13. Brown SE, Coddington CC, Schnorr J, Toner JP, Gibbons W, Oehninger S. Evaluation of outpatient hysteroscopy, saline infusion hysterosonography, and hysterosalpingography in infertile women: A prospective, randomized study. Fertil Steril. 2000;74:1029-34.

14. Mooney SB, Milki AA. Effect of hysteroscopy performed in the cycle preceding controlled ovarian hyperstimulation on the outcome of in vitro fertilisation. Fertil Steril. 2003;79:637-8.

15. Homer HA, Li TC, Cooke ID. The septate uterus: A review of management and reproductive outcome. Fertil Steril. 2000;73:1-14.

16. Kamiński P, Wieczorek K, Marianowski L. Usefulness of hysteroscopy in diagnosing sterility. Ginekol Pol.1992;63:634-7.

17. Donnez J, Jadoul P. What are the implications of myomas on fertility? A need for a debate? Hum Reprod.2002;17:1424-30.

18. Pritts EA. Fibroids and infertility: A systematic review of the evidence. Obstet Gynecol Surv. 2001;56:483-91.

19. Hinckley MD, Milki AA. 1000 office-based hysteroscopies prior to in vitro fertilization: Feasibility and findings. JSLS. 2004;8:103-7.

20. Shalev J, Meizner I, Bar-Hava I, Dicker D, Mashiach $\mathrm{R}$, Ben-Rafael Z. Predictive value of transvaginal sonography performed before routine diagnostic hysteroscopy for evaluation of infertility. Fertil Steril. 2000;73:412-7.

21. Shokeir TA, Shalan HM, EI-Shafei MM. Significance of endometrial polyps detected hysteroscopically in eumenorrheic infertile women. J Obstet Gynaecol Res. 2004;30:84-9.

Cite this article as: Mehta AV, Modi AP, Raval BM, Munshi SP, Patel SB, Dedharotiya SM. Role of diagnostic hysterolaparoscopy in the evaluation of infertility. Int J Reprod Contracept Obstet Gynecol 2016;5:437-40. 